\title{
PENERAPAN PROGRAM THE GOOD BEHAVIOR GAMES (GBG) UNTUK MENINGKATKAN PERILAKU PROSOSIAL PADA BYSTANDER
}

\author{
Yunike Putri ${ }^{1}$, Sri Tiatri ${ }^{2}$, Pamela Hendra Heng ${ }^{3}$ \\ ${ }^{1}$ Fakultas Psikologi, Universitas Tarumanagara Jakarta \\ Email: yunike.707181002@stu.untar.ac.id \\ ${ }^{2}$ Fakultas Psikologi, Universitas Tarumanagara Jakarta \\ Email: sri.tiatri@untar.ac.id \\ ${ }^{3}$ Fakultas Psikologi, Universitas Tarumanagara Jakarta \\ Email:pamelah@fpsi.untar.ac.id
}

Masuk : 21-04-2020, revisi: 28-04-2020, diterima untuk diterbitkan : 30-04-2020

\begin{abstract}
Bullying is not only affects victims of bullying, but it can also affect students who witness bullying (bystander). The role of the bystander becomes very important because as someone who often witnesses the bullying, they can prevent the incident. A bystander who is often passive in stopping bullying has been found to have a low quality prosocial behavior. In doing prosocial behavior, one of very important thing to do is to give reinforcement to children. In the Good Behavior Games (GBG) program, students in groups will be given instructions in a game to do various prosocial behavior. Students will be given reinforcement, which is the compilation of rewards if they can show the expected behavior. The purpose of this research is to examine whether the implementation of the Good Behavior Games (GBG) program can increase prosocial behavior of bystander in 6th grade students. This study used an experimental design of one group pre-test post-test involving 27 participants who were identified as bystanders. The sampling technique in this study used purposive sampling. Measurements in this study used a Prosocial Behavior measurement tool developed by Knafo Noam et al. The GBG implementation was carried out in 22 sessions. The results showed that the Good Behavior Games intervention program was able to increase prosocial behavior of bystanders.
\end{abstract}

Keywords: prosocial behavior, bystanders, the Good Behavior Games

\begin{abstract}
ABSTRAK
Kejadian bullying tidak hanya mempengaruhi korban bullying, tetapi hal tersebut juga dapat memengaruhi siswasiswa yang menyaksikan kejadian bullying (bystander). Peran bystander menjadi sangat penting, karena sebagai seseorang yang seringkali menyaksikan bullying, mereka dapat mencegah kejadian tersebut. Seorang bystander yang seringkali bersikap pasif dalam menghentikan bullying ditemukan memiliki kualitas perilaku prososial yang rendah. Dalam mengajarkan perilaku prososial, salah satu hal yang sangat penting untuk dilakukan yaitu dengan memberikan reinforcement atau penguatan pada anak. Dalam program the Good Behavior Games (GBG) para siswa dalam kelompok diberikan instruksi untuk melakukan berbagai perilaku prososial dalam suatu permainan. Siswa diberi reinforcement, yaitu berupa reward ketika berhasil menunjukkan perilaku yang diharapkan. Tujuan dari penelitian ini adalah untuk menguji apakah penerapan program the Good Behavior Games (GBG) dapat meningkatkan perilaku prososial pada bystander pada siswa kelas 6 SD. Penelitian ini menggunakan desain eksperimen one group pre-test post-test dengan melibatkan 27 partisipan yang teridentifikasi sebagai seorang bystander. Teknik pengambilan sampel dalam penelitian ini menggunakan purposive sampling. Pengukuran dalam penelitian ini menggunakan alat ukur Perilaku Prososial yang dikembangkan oleh Knafo Noam dkk. Pelaksanaan the GBG dilaksanakan sebanyak 22 sesi. Hasil penelitian menunjukkan pemberian intervensi program the Good Behavior Games dapat meningkatkan perilaku prososial pada bystander.
\end{abstract}

Kata Kunci: perilaku prososial, bystander, the Good Behavior Games

\section{PENDAHULUAN}

\section{Latar Belakang}

Kejadian bullying adalah salah satu permasalahan yang semakin marak terjadi di kalangan siswa di sekolah. Berdasarkan data dari KPAI, per tanggal 20 Mei 2018, dalam data bidang pendidikan, kasus anak pelaku kekerasan dan bullying adalah kasus yang paling banyak terjadi, yaitu dengan rinciannya; anak pelaku kekerasan dan bullying sebanyak 41 (25,5\%) kasus, anak korban 
kekerasan dan bullying sebanyak $36(22,4 \%)$ kasus, anak pelaku tawuran sebanyak $31(19,3 \%)$ kasus, anak korban kebijakan (pungli, dikeluarkan dari sekolah, tidak boleh ikut ujian, dan putus sekolah) sebanyak 30 (18,7\%) kasus, dan anak korban tawuran sebanyak 23 (14,3\%) kasus (Widiastuti, 2018). Tidak hanya di dalam negeri, berdasarkan data dari Departemen Pendidikan Amerikat Serikat, lebih dari 25\% siswa menyatakan bahwa mereka pernah menjadi korban dari bullying, baik berupa bullying dalam bentuk fisik, verbal atau secara sengaja menyebarkan rumor atau mengucilkan diri dari kelompok (Midgett et al., 2017).

Kejadian bullying tidak hanya mempengaruhi korban-korban yang mengalami penderitaan secara langsung dari pelaku, tetapi kejadian tersebut juga dapat mempengaruhi siswa-siswa lain yang menyaksikan kejadian bullying (bystander). Kejadian bullying dapat merusak budaya sekolah yang dianggap menerima perilaku bullying dan sebagai seorang siswa yang menjadi bystander akan beranggapan bahwa mereka tidak memiliki kekuatan untuk menghentikan hal tersebut (Raskauskas et al., 2010). Peran dari bystander menjadi topik penelitian yang sangat populer karena dapat mencegah perilaku bullying. Kejadian bullying terjadi dikarenakan adanya situasi yang tidak seimbang di antara pelaku dan korban bullying. Sebagai seorang bystander yang seringkali menyaksikan kejadian bullying, mereka dapat memiliki kemampuan untuk mencegah perilaku agresif (Song \& Oh, 2017).

Namun, kehadiran siswa lain dalam kejadian bullying sangat disayangkan tidak cukup mencegah perilaku bullying yang dilakukan. Sebaliknya, inti dari kejadian bullying terjadi diakibatkan adanya keterlibatan yang secara tidak langsung dari para bystander yang menyaksikan kejadian bullying dan seringkali mendukung atau memberikan dorongan baik secara aktif maupun pasif (Trach et al., 2010). Dalam penelitian, bystander dibagi menjadi empat kelompok yaitu: seorang asisten, seorang penguat, orang luar, dan seorang pembela. Keempat kelompok tersebut dibagi berdasarkan sejauh mana peran mereka dalam membela korban. Seorang asisten adalah seorang yang ikut terlibat dalam bullying, seorang penguat adalah seorang yang mendukung pelaku secara tidak langsung, orang luar adalah seorang pengamat yang hanya mengamati situasi, sedangkan seorang pembela adalah seorang yang berusaha atau terlibat secara langsung untuk menghentikan kejadian bullying secara langsung (Song \& Oh, 2017).

Penelitian yang dilakukan oleh Salmivalli pada siswa kelas 6 SD di tahun 1999, menemukan bahwa terdapat $20 \%$ siswa yang teridentifikasi sebagai penguat yang secara aktif mendorong pelaku dalam melakukan bullying, dan sekitar 7\% siswa yang teridentifikasi sebagai seorang asisten dari pelaku. Hanya $17 \%$ siswa yang teridentifikasi sebagai seorang pembela korban, dan sebagian besar (24\%) siswa lainnya hanya hanya berperilaku sebagai seorang pengamat pasif. Selain itu, dari sebuah pengamatan ditemukan, meskipun siswa sekolah dasar menyaksikan langsung $85 \%$ kejadian bullying di sekolah, hanya sekitar $25 \%$ siswa yang melakukan intervensi dan sebagian besar siswa hanya berperan pasif menyaksikan kejadian tersebut (54\%) atau secara aktif terlibat dalam bullying $(21 \%)$. Hal tersebut menunjukkan bahwa perilaku siswa sebagai seorang bystander dalam membela atau menolong korban bullying cenderung rendah (Trach et al., 2010).

Hal yang sama ditemukan oleh peneliti di sebuah sekolah dasar X di Jakarta. Berdasarkan hasil personal communication dengan seorang wali kelas dan observasi langsung yang dilakukan di SD X pada tanggal 13 Mei 2019, peneliti menemukan masih banyaknya siswa di kelas 6 yang seringkali tidak peduli ketika menyaksikan temannya yang menjadi korban bullying. Ketika menyaksikan temannya diejek atau dicemooh, para siswa lainnya umumnya hanya diam atau justru ikut mencemooh dan menyoraki. Para siswa tersebut seringkali tidak membela atau membantu 
temannya yang menjadi korban bullying tersebut. Selain berbentuk verbal, perilaku bullying dalam bentuk fisik juga beberapa kali terlihat seperti mendorong atau menendang teman lain. Menurut wali kelas, berbagai karakteristik perilaku di atas merupakan salah satu permasalahan yang sangat sulit untuk ditangani.

Perilaku yang ditunjukkan oleh bystander menunjukkan adanya kecenderungan perilaku prososial dengan atribut perilaku menolong (Howard, Landau \& Pryor, 2013). Selain itu, Pozzoli, Gini dan Ang (2012) menyatakan perilaku-perilaku seperti membela dalam menghentikan perilaku bullying, membantu dan menghibur korban atau meminta tolong dari orang dewasa merupakan beberapa perilaku prososial lainnya. Dalam penelitian yang dilakukan oleh Gini dkk., (2008), ditemukan bahwa seorang bystander yang dapat berperan aktif dalam membela korban bullying memiliki kualitas perilaku prososial yang tinggi. Menurut Schacter dan Juvonen (2018), semakin tingginya perilaku prososial yang dimiliki oleh siswa di sekolah dapat membantu korban dari berbagai perilaku yang tidak menyenangkan dan mengurangi tekanan pada korban bullying.

Meskipun perilaku prososial sudah berkembang sejak usia dini, tetapi sangat disayangkan ketika menyaksikan kesulitan atau perilaku bullying yang terjadi pada temannya, pada anak usia sekolah dasar jarang sekali untuk memberikan pertolongan atau merasa kurang bertanggung jawab (Gini et al., 2008). Menurut Huitsing et al. (2014) promosi perilaku prososial dapat meningkatkan kesadaran diri seseorang mengenai bullying dan keterlibatan teman sebaya di sekolah. Hal tersebut dinilai efektif untuk meningkatkan keterampilan untuk sukses dalam konteks sosial dan mengurangi kasus bullying di sekolah.

Ketika mengajarkan perilaku prososial pada anak, menurut Biglan et al. (2012), pemberian reinforcement atau penguatan adalah hal yang sangat penting untuk dilakukan. Selain itu, menurut Hogg dan Vaughan (2011) terdapat beberapa cara untuk mengajarkan anak mengenai perilaku prososial, seperti memberikan instruksi, reinforcement dan modelling pada anak. Dalam teori behaviorisme, asumsi dasar dari pemberian reinforcement yaitu dapat meningkatkan suatu perilaku, karena perilaku tersebut berhubungan dengan konsekuensi yang positif. Dalam sebuah intervensi singkat selama satu bulan ketika guru terus memberikan reinforcement berupa pemberian bintang ketika siswa mampu menunjukkan perilaku prososial seperti berbagi, menolong dan bekerja sama dengan teman, jenis reinforcement tersebut ditemukan efektif dalam meningkatkan perilaku prososial (Ramaswamy, \& Bergin, 2009).

Salah satu teori belajar behavioristik yang mengusung konsep reinforcement adalah teori operant conditioning yang dikemukakan oleh B.F Skinner. Konsep reinforcement adalah sebuah konsekuensi yang dapat meningkatkan kemungkinan suatu perilaku muncul. Terdapat enam strategi dari operant conditioning untuk meningkatkan suatu perilaku pada siswa, yaitu, (a) Pemilihan reinforcers atau penguat yang tepat; (b) Pemberian reinforcers kontingen dan tepat waktu; (c) Pemilihan waktu terbaik dalam pemberian reinforcement; (d) Penggunaan kesepakatan kontrak dengan siswa; (e) Penggunaan reinforcement negatif secara efektif; (f) Penggunaan instruksi dan pembentukan perilaku atau shaping (Santrock, 2015).

Keenam konsep dari operant conditioning di atas digunakan dalam the Good Behavior Games (GBG). Program the Good Behavior Games (GBG) adalah sebuah program yang pertama kali disusun oleh Barris, Saudiers dan Wolf pada tahun 1969. Aspek besar dari GBG yang dideskripsikan oleh Barrish (1969) mencakup beberapa poin: (a) membentuk siswa menjadi beberapa kelompok, (b) memberikan poin kepada kelompok yang menunjukkan perilaku yang sesuai dan (c) memberikan reward pada kelompok yang paling sedikit menunjukkan perilaku 
bermasalah. Dalam beberapa penelitian the GBG juga telah dimodifikasi dengan beberapa cara seperti memberikan reward pada perilaku-perilaku yang sesuai, menambahkan sistem pujian pada siswa yang terlibat dalam akademik, menambahkan intervensi perilaku, menambahkan komponen self-monitoring, tidak menggunakan sistem kelompok, menilai ketergantungan kelompok, dan membiarkan seorang individu untuk mendapatkan poin (Bowman-Perrot et al., 2016).

Dalam program the Good Behavior Games (GBG) pada penelitian ini, para siswa dalam kelompok diberikan instruksi dalam suatu permainan, yaitu untuk berperilaku prososial seperti menolong, menghibur atau berperilaku baik. Guru memilih waktu terbaik dan panjangnya durasi ketika menerapkan the GBG di kelas. Selain itu, pada the GBG, setiap siswa juga diberikan reinforcement, yaitu berupa reward bagi kelompok siswa yang berhasil menunjukkan perilaku yang diharapkan. Selain mendapatkan contoh dari guru, para siswa juga saling belajar satu sama lain. Guru terus memberikan apresiasi perilaku-perilaku prososial yang ditunjukkan oleh siswa. Melalui program the GBG diharapkan dapat meningkatkan perilaku prososial pada partisipan sebagai seorang bystander. Dengan meningkatnya perilaku prososial pada partisipan, maka hal tersebut diharapkan dapat mengurangi tingkat bullying di sekolah.

Dikarenakan kesederhanaan dan bukti dalam jangka panjangnya, program the GBG disebut sebagai "behavioral vaccine" (Donaldson et al., 2011). Salah satu penelitian terkait yang menggunakan program the $G B G$ pernah digunakan oleh Rubow et al. (2018) terhadap siswa di kelas empat dan kelas delapan. Dalam penelitian ini, penerapan program the GBG ditemukan dapat mengurangi perilaku menyimpang di kelas. Sejalan dengan penelitian Rusbow dkk, pada penelitian yang dilakukan oleh Ruiz-Olivares, Pino dan Herruzo (2010) ditemukan pemberian intervensi program the GBG efektif mengurangi perilaku mengganggu di dalam kelas. Di Indonesia sendiri, penggunaan program serupa diteliti oleh Wijayanti (2018) dan terbukti bahwa program the GBG dapat mengurangi perilaku mengganggu pada siswa kelas $\mathrm{V}$ sekolah dasar. Selain mengurangi perilaku mengganggu di kelas, sebuah penelitian Robertshaw dan Hiebert pada tahun 1973 (dalam Tingstrom et al., 2006) program the GBG ditemukan mampu meningkatkan perilaku prososial pada siswa kelas satu SD seperti mengerjakan tugas yang diberikan, menunggu dengan sabar ketika meminta tolong dan memindahkan kursi secara perlahan.

Penelitian mengenai penerapan the GBG umumnya hanya berfokus untuk menurunkan berbagai perilaku mengganggu atau antisosial seperti perilaku disruptif atau agresif di kelas. Penelitian asing mengenai penerapan the GBG untuk meningkatkan perilaku prososial masih sangat terbatas dan penelitian yang dilakukan juga sudah terlalu lama dilakukan yaitu pada tahun 1970an. Di Indonesia sendiri, beberapa penelitian mengenai penerapan the GBG dilakukan untuk mengurangi perilaku disruptif bukan untuk meningkatkan perilaku positif misalnya perilaku prososial. Selain itu, penelitian the GBG yang menggunakan bystander bullying sebagai partisipan penelitian juga masih belum ditemukan. Oleh karena itu, peneliti tertarik melakukan penelitian untuk melihat apakah penerapan program the Good Behavior Games (GBG) dapat meningkatkan perilaku prososial pada bystander pada siswa kelas 6 di SD X.

"Apakah penerapan program the Good Behavior Games (GBG) dapat meningkatkan perilaku prososial pada bystander di sekolah dasar X?" 


\section{METODE PENELITIAN Partisipan}

Partisipan dalam penelitian ini adalah 27 siswa kelas 6 di SD X yang terdiri dari 13 partisipan lakilaki dan 14 partisipan perempuan. Teknik pengambilan sampel dalam penelitian ini menggunakan purposive sampling yaitu penentuan partisipan penelitian yang didasarkan pada pertimbangan peneliti dan pihak sekolah yaitu siswa yang memiliki karakteristik yang sesuai dengan topik penelitian yang diambil. Partisipan yang terpilih adalah para siswa di kelas 6A yang teridentifikasi sebagai bystander atau siswa yang seringkali menyaksikan kejadian bullying pada teman-teman sekelasnya atau kadangkala menjadi korban perilaku buruk dari pelaku.

\section{Desain Penelitian}

Desain penelitian yang digunakan dalam penelitian ini adalah kuasi eksperimen One Group Pretest Post-test Design. Pada langkah pertama, peneliti memberikan pretest berupa kuesioner perilaku prososial pada siswa. Berdasarkan hasil pre-test, observasi, dan wawancara dengan wali kelas, selanjutnya peneliti mengidentifikasi siswa yang berperan sebagai bystander untuk dijadikan partisipan dalam penelitian ini. Dari 31 siswa di kelas 6A, terdapat 27 siswa yang teridentifikasi sebagai seorang bystander. Selanjutnya, kelompok siswa tersebut diberikan perlakuan berupa sebuah program intervensi Good Behavior Games (GBG). Pada langkah terakhir, seluruh partisipan penelitian diberikan post-test berupa kuesioner yang sama untuk melihat pengaruh dari pemberian program intervensi terhadap perilaku prososial pada bystander.

\section{Pengukuran}

Pengukuran dalam penelitian ini menggunakan alat ukur Perilaku Prososial yang dikembangkan oleh Knafo Naom et al. pada tahun 2015. Alat ukur ini terdiri dari 20 item dengan 4 dimensi untuk mengukur perilaku prososial yaitu perilaku empati, perilaku menolong, perilaku baik, perilaku berbagi dan perilaku kepedulian sosial. Skala yang digunakan dalam alat ukur ini terdiri dari skala 1-3, yaitu poin 1 untuk "Tidak Benar", poin 2 untuk "Agak Benar" dan poin 3 untuk "Benar".

\section{Prosedur Intervensi}

Langkah-langkah dasar intervensi yang digunakan dalam penelitian ini dirancang berdasarkan aspek besar yang dirancang oleh oleh Barrish (1969) mencakup beberapa poin, seperti membentuk siswa menjadi beberapa kelompok, memberikan poin kepada kelompok yang menunjukkan perilaku yang sesuai dan memberikan reward pada kelompok yang paling sedikit menunjukkan perilaku bermasalah (Bowman-Perrot et al., 2016). Penulis kemudian menambahkan beberapa poin tambahan dalam program intervensi yang dilakukan seperti adanya sistem pengurangan poin kelompok ketika ada anggota kelompok yang melakukan perilaku tidak baik.

Langkah pertama, peneliti dan wali kelas melakukan diskusi untuk menentukan pembagian kelompok sebagai bagian penting dari program the Good Behavior Games. Kelompok kemudian dibagi menjadi 3, yang terdiri dari 10-11 partisipan pada setiap kelompok. Pada setiap kelompok terdiri dari 1-2 siswa yang teridentifikasi sebagai pelaku bullying dan 8-10 siswa yang teridentifikasi sebagai seorang bystander berdasarkan hasil pre-test sebelumnya. Pelaksanaan kegiatan intervensi dilakukan sebanyak 22 sesi selama 8 hari. Pada hari pertama, kegiatan intervensi hanya dilakukan selama satu sesi. Selanjutnya pada hari kedua sampai kedelapan, kegiatan intervensi dilakukan sebanyak 3 sesi setiap harinya yaitu sesi pertama pada pukul 07.2008.00, sesi kedua pada pukul 09.00-09.40 dan sesi terakhir pada pukul 10.30-11.10.

Pemberian intervensi the $G B G$ dimulai dengan pemberian poster mengenai perilaku-perilaku prososial yang harus dilakukan partisipan dan perilaku-perilaku negatif yang tidak boleh 
dilakukan. Partisipan yang dapat menunjukkan perilaku positif yang diharapkan, maka kelompok partisipan tersebut berhak mendapatkan poin dan sebaliknya setiap partisipan yang menunjukkan perilaku negatif, maka kelompok partisipan tersebut mendapatkan pengurangan poin. Bagi kelompok partisipan yang berhasil mendapatkan skor terbanyak berhak menjadi pemenang dan mendapatkan rewards yang disediakan oleh peneliti berupa alat tulis (pulpen, notebook kecil, tipe $\mathrm{x}, \mathrm{dsb}$ ), camilan (cookies dan cokelat) atau mainan kecil.

\section{Rancangan Penyusunan Modul Intervensi}

Penyusunan modul intervensi dalam penelitian ini disusun berdasarkan 5 dimensi dari alat ukur perilaku prososial yang digunakan yaitu perilaku baik, perilaku menolong, perilaku berbagi, perilaku empati dan perilaku kepedulian sosial. Rincian rancangan kegiatan intervensi yang dilakukan dapat dilihat pada tabel 1 .

Tabel 1. Rancangan Kegiatan Intervensi

\begin{tabular}{|c|c|c|c|c|c|}
\hline Pertemuan & Sesi & Materi & Waktu & Metode & Media \\
\hline 1 & 1 & $\begin{array}{l}\text { Pengenalan perilaku prososial, } \\
\text { pengenalan program the Good } \\
\text { Behavior Games, pembagian } \\
\text { kelompok }\end{array}$ & $60^{\prime}$ & $\begin{array}{l}\text { Ceramah } \\
\text { dan } \\
\text { diskusi }\end{array}$ & \\
\hline 2 & $2-4$ & $\begin{array}{l}\text { Kindness (Perilaku Baik) } \\
\text { Partisipan diminta untuk } \\
\text { menunjukkan perilaku baik } \\
\text { seperti, memberikan pujian pada } \\
\text { teman, memberikan dorongan } \\
\text { pada teman dan berbicara dengan } \\
\text { kata-kata baik. Sebaliknya, } \\
\text { partisipan akan mendapatkan } \\
\text { pengurangan poin jika } \\
\text { melakukan perilaku tidak baik } \\
\text { seperti, meledek atau menertawai } \\
\text { teman dan berbicara kata-kata } \\
\text { kasar. }\end{array}$ & $\begin{array}{l}\text { Sesi 2-4 } \\
\text { (40’ pada } \\
\text { setiap } \\
\text { sesinya) }\end{array}$ & $\begin{array}{l}\text { Games, } \\
\text { Ceramah } \\
\text { dan } \\
\text { diskusi }\end{array}$ & $\begin{array}{c}\text { Papan Chart } \\
\text { Kelompok, } \\
\text { stiker } \\
\text { bintang, } \\
\text { poster } \\
\text { peraturan, } \\
\text { kertas post- } \\
\text { it }\end{array}$ \\
\hline 3 & $5-7$ & $\begin{array}{l}\text { Helping (Perilaku Menolong) } \\
\text { Partisipan diminta untuk } \\
\text { menunjukkan perilaku menolong } \\
\text { seperti, membantu teman yang } \\
\text { kesulitan atau membantu teman } \\
\text { yang diganggu teman lain dengan } \\
\text { menegur atau melaporkan } \\
\text { kepada guru. Sebaliknya, } \\
\text { partisipan akan mendapatkan } \\
\text { pengurangan poin jika } \\
\text { melakukan perilaku negatif } \\
\text { seperti, ikut mengganggu teman, } \\
\text { mengabaikan atau menolak } \\
\text { membantu teman yang kesulitan. }\end{array}$ & $\begin{array}{l}\text { Sesi 5-7 } \\
\text { (40’ pada } \\
\text { setiap } \\
\text { sesinya) }\end{array}$ & $\begin{array}{l}\text { Games, } \\
\text { Ceramah } \\
\text { dan } \\
\text { diskusi }\end{array}$ & $\begin{array}{c}\text { Video, kartu } \\
\text { merit, } \\
\text { booklet } \\
\text { partisipan, } \\
\text { poster } \\
\text { peraturan }\end{array}$ \\
\hline
\end{tabular}




\begin{tabular}{|c|c|c|c|c|c|}
\hline 4 & $8-10$ & $\begin{array}{l}\text { Sharing (Perilaku Berbagi) } \\
\text { Partisipan diminta untuk } \\
\text { menunjukkan perilaku berbagi } \\
\text { seperti berbagi makanan atau alat } \\
\text { tulis dengan temannya. } \\
\text { Sebaliknya, partisipan akan } \\
\text { mendapatkan pengurangan poin } \\
\text { jika menolak untuk berbagi atau } \\
\text { meledek teman lain yang tidak } \\
\text { memiliki sesuatu. }\end{array}$ & $\begin{array}{l}\text { Sesi 8-10 } \\
\text { (40’ pada } \\
\text { setiap } \\
\text { sesinya) }\end{array}$ & $\begin{array}{l}\text { Games, } \\
\text { Ceramah } \\
\text { dan } \\
\text { diskusi }\end{array}$ & $\begin{array}{l}\text { Snack, kartu } \\
\text { merit dan } \\
\text { poster } \\
\text { peraturan }\end{array}$ \\
\hline 5 & $11-13$ & $\begin{array}{l}\text { Empathy (Perilaku empati) } \\
\text { Partisipan diminta untuk } \\
\text { menunjukkan perilaku empati } \\
\text { seperti bertanya perasaan teman } \\
\text { yang sedang sedih atau terluka } \\
\text { atau mengibur teman yang } \\
\text { sedang sedih atau kesal. } \\
\text { Sebaliknya, partisipan akan } \\
\text { mendapatkan pengurangan poin } \\
\text { jika berperilaku negatif seperti } \\
\text { meledek atau berkata kasar pada } \\
\text { teman yang sedang sedih, kesal } \\
\text { atau terluka. }\end{array}$ & $\begin{array}{l}\text { Sesi } 11-13 \\
\text { (40' pada } \\
\text { setiap } \\
\text { sesinya) }\end{array}$ & $\begin{array}{l}\text { Games, } \\
\text { Ceramah } \\
\text { dan } \\
\text { diskusi }\end{array}$ & $\begin{array}{c}\text { Kartu } \\
\text { undian } \\
\text { untuk } \\
\text { pemenang, } \\
\text { poster } \\
\text { peraturan } \\
\text { dan LK } \\
\text { empati }\end{array}$ \\
\hline 6 & $14-16$ & $\begin{array}{l}\text { Social Concern (Kepedulian } \\
\text { sosial) } \\
\text { Partisipan diminta untuk } \\
\text { menunjukkan } \\
\text { kepedulian sosial } r \text { seperti } \\
\text { mengajak teman untuk bermain } \\
\text { bersama atau berusaha untuk } \\
\text { menghentikkan pertengkaran } \\
\text { teman. Sebaliknya, partisipan } \\
\text { akan mendapatkan pengurangan } \\
\text { poin jika berperilaku negatif } \\
\text { seperti tidak mau bermain } \\
\text { bersama teman, ikut meledek } \\
\text { atau mengabaikan pertengkaran } \\
\text { teman. }\end{array}$ & $\begin{array}{c}\text { Sesi } 14-16 \\
\text { (40’ pada } \\
\text { setiap } \\
\text { sesinya) }\end{array}$ & $\begin{array}{l}\text { Games, } \\
\text { Ceramah } \\
\text { dan } \\
\text { diskusi }\end{array}$ & $\begin{array}{c}\text { Kartu } \\
\text { undian } \\
\text { untuk } \\
\text { pemenang, } \\
\text { poster } \\
\text { peraturan }\end{array}$ \\
\hline 7 dan 8 & $17-22$ & $\begin{array}{l}\text { Prosocial Behavior (Perilaku } \\
\text { Prososial) } \\
\text { Integrasi dari keseluruhan } \\
\text { dimensi perilaku prososial yang } \\
\text { sudah dilakukan sebelumnya. } \\
\text { Partisipan diminta untuk } \\
\text { melakukan berbagai perilaku } \\
\text { baik, menolong, berbagi, empati } \\
\text { dan kepedulian sosial seperti di } \\
\text { sesi-sesi sebelumnya. }\end{array}$ & $\begin{array}{c}\text { Sesi } \\
17-22 \\
\text { (40’ pada } \\
\text { setiap } \\
\text { sesinya) }\end{array}$ & & $\begin{array}{l}\text { Stiker } \\
\text { dengan } \\
\text { nama } \\
\text { kelompok, } \\
\text { papan } \\
\text { "Good } \\
\text { Board", } \\
\text { poster } \\
\text { peraturan, } \\
\text { stik es krim, }\end{array}$ \\
\hline
\end{tabular}




\begin{tabular}{ll}
\hline Sebaliknya, partisipan akan & LK perilaku \\
mendapatkan pengurangan poin & prososial \\
jika berperilaku negatif seperti & \\
meledek atau menertawai teman, & \\
berkata kasar pada teman, & \\
menyalahkan teman sekelompok, & \\
dsb. &
\end{tabular}

\section{HASIL DAN PEMBAHASAN}

Hasil penelitian menunjukkan adanya gain score dari perbandingan skor pre-test dan post-test dari partisipan penelitian. Berdasarkan hasil gain score antara pre-test dan post-test, terdapat peningkatan skor pada 26 partisipan dari total keseluruhan 27 partisipan. Kenaikan skor terendah yaitu sebesar 1 poin dan kenaikan tertinggi yaitu sebesar 11 poin. Terdapat 4 partisipan yang sebelumnya berada pada kategori rendah pada hasil pre-test mengalami kenaikan ke dalam kategori cukup pada hasil post-test. Selain itu, sebanyak 8 partisipan yang sebelumnya berada pada kategori sedang pada hasil pre-test mengalami peningkatan ke dalam kategori tinggi pada hasil post-test. Analisis lebih lanjut menggunakan uji beda paired sample t-test pada hasil skor pre-test dan post-test, didapatkan bahwa terdapat perubahan yang signifikan perilaku prososial pada partisipan penelitian $(\mathrm{t}=-9.597, \mathrm{p}<0.05)$. Hal ini dapat diartikan bahwa penerapan the Good Behavior Games (GBG) dapat meningkatkan perilaku prososial pada partisipan penelitian.

Selanjutnya, peneliti ingin membahas berbagai temuan sepanjang penelitian berlangsung. Selama kegiatan intervensi berlangsung, partisipan penelitian terlihat secara aktif menujukkan perilaku prososial. Hal yang seringkali terlihat adalah ketika partisipan mampu menunjukkan perilaku menolong dan membela korban bullying yang kerap kali diejek atau disoraki dengan menegur langsung pelaku atau melaporkannya kepada guru. Selain perilaku membela dan menolong, beberapa partisipan juga mampu menunjukkan perilaku empati seperti menghibur dan menanyakan keadaan temannya yang sedang sedih atau sedang sakit. Beberapa partisipan juga mampu menunjukkan perilaku kepedulian pada temannya, hal ini ditunjukkan dengan mengajak seorang siswa lain yang umumnya selalu menghabiskan waktu sendirian untuk berkumpul dan bermain bersama. Selain beberapa perilaku tersebut, peneliti juga melihat berbagai perilaku baik yang ditunjukkan oleh partisipan seperti menolong temannya yang terjatuh, mengantarkan temannya yang sedang sakit ke UKS atau membantu teman ketika mengerjakan tugas bersama. Selain itu, hampir semua partisipan juga menunjukkan perilaku berbagi satu sama lain seperti berbagi makanan dan berbagi alat tulis.

Hasil penelitian ini sejalan dengan hasil temuan penelitian yang dilakukan oleh Robertshaw dan Hiebert pada tahun 1973 (dalam Tingstrm, Sterling-Turner \& Wilczynski, 2006), yang menyatakan bahwa melalui penerapan the Good Behavior Games (GBG) dapat meningkatkan perilaku sosial positif pada siswa kelas satu sekolah dasar (SD) seperti siswa mampu mengerjakan tugas yang diberikan atau menunggu dengan sabar ketika meminta tolong. Menurut Biglan dkk., (2012) dalam mengajarkan perilaku prososial, hal yang sangat penting untuk di lakukan yaitu dengan memberikan reinforcement atau penguatan pada anak. Asumsi dasar dari teori behaviorisme yaitu reinforcement dapat meningkatkan suatu perilaku, hal tersubut disebabkan oleh perilaku tersebut menjadi berhubungan dengan konsekuensi yang positif (Ramaswamy, \& Bergin, 2009). Dalam sebuah intervensi singkat selama satu bulan ketika guru terus memberikan reinforcement berupa pemberian bintang ketika siswa mampu menunjukkan perilaku prososial seperti berbagi, menolong dan bekerja sama dengan teman, jenis reinforcement tersebut ditemukan 
efektif dalam meningkatkan perilaku prososial (Ramaswamy, \& Bergin, 2009). Dalam penerapan the $G B G$, konsep reinforcement adalah hal penting yang tidak dapat dipisahkan karena setiap kali siswa mampu menunjukkan perilaku yang diharapkan, maka siswa akan mendapatkan penguatan atau rewards. Konsep tersebut yang dapat menjadi salah satu faktor keberhasilan dari penerapan intervensi pada penelitian ini.

Penelitian ini menyatakan bahwa penerapan the Good Behavior Games (GBG) dapat meningkatkan perilaku prososial pada bystander. Namun, terdapat beberapa kekurangan yang tidak luput dalam penelitian ini. Pertama, peneliti tidak melakukan kontrol terhadap berbagi faktor yang dapat mempengaruhi perilaku prososial pada partisipan penelitian. Kedua yaitu adanya aturan program intervensi the $G B G$ yang memiliki durasi pada setiap sesinya, di mana partisipan tidak berhak mendaptkan poin jika melakukan perilaku positif ketika sesi sudah berkahir. Ketiga, penggunaan alat ukur yang digunakan dalam penelitian ini. Dalam penelitian ini peneliti menggunakan alat ukur untuk perilaku prososial secara umum bukan untuk mengukur perilaku prososial khusus untuk bystander. Keempat, adanya sistem rewards bagi kelompok pemenang. Hal tersebut membuat peneliti kesulitan untuk melihat apakan perilaku positif yang ditunjukkan oleh partisipan didasarkan atas niat baik partisipan atau keinginan untuk mendapatkan rewards dalam permainan.

\section{KESIMPULAN DAN SARAN}

Berdasarkan hasil penelitian, maka dapat disimpulkan bahwa penerapan the Good Behavior Games (GBG) dapat meningkatkan perilaku prososial pada bystander. Terdapat perbedaan perilaku prososial pada partisipan penelitian sebelum dan sesudah diberikan intervensi. Beberapa perilaku prososial yang ditunjukkan dalam penelitian ini, yaitu perilaku baik, perilaku menolong, perilaku berbagi, perilaku empati dan perilaku kepedulian sosial. Dengan meningkatnya perilaku prososial pada bystander diharapkan dapat mengurangi perilaku bullying di sekolah.

Terdapat beberapa saran yang dapat diberikan dalam penelitian ini. Pertama, bagi peneliti selanjutnya. Peneliti menyarankan peneliti selanjutnya untuk menggunakan desain eksperimen lain misalnya, desain pretest-posttest control group untuk meningkatkan validitas internal penelitian yang lebih tinggi. Peneliti selanjutnya juga dapat menggunakan metode penelitian lain seperti mixed method untuk mendapatkan gambaran penelitian yang lebih rinci. Selain itu, peneliti selanjutnya disarankan untuk mengembangkan alat ukur perilaku prososial khusus untuk bystander. Peneliti selanjutnya juga disarankan untuk meneliti dan mengontrol faktor-faktor apa saja yang dapat mempengaruhi perilaku prososial pada partisipan.

Saran kedua adalah saran praktis untuk siswa, orang tua dan guru atau pihak sekolah. Siswa disarankan untuk menunjukkan perilaku-perilaku prososial dalam kehidupan sehari-harinya khususnya untuk mencegah berbagai kejadian bullying. Bagi orang tua, peneliti menyarankan untuk mengajarkan anak berbagai perilaku-perilaku prososials sejak dini. Terakhir, peneliti menyarankan guru dan pihak sekolah untuk menerapkan program intervensi the GBG untuk mengurangi berbagai perilaku negatif di sekolah dan mengembangkan program intervensi khusus yang bertujuan untuk mengurangi perilaku bullying di sekolah.

\section{Ucapan Terima Kasih (Acknowledgement)}

Penulis mengucapakan terima kasih kepada para pimpinan, guru dan para siswa di SD X yang terlibat dalam penelitian ini. Selain itu, penulis juga berterima kasih kepada berbagi pihak yang mereview penelitian ini. 


\section{REFERENSI}

Biglan, A., Flay, B. R., Embry, D. D., \& Sandler, I. N. (2012). The critical role of nurturing environments for promoting human well-being. American Psychologist, 67(4), 257271. doi:10.1037/a0026796

Bowman-Perrott, L., Burke, M. D., Zaini, S., Zhang, N., \& Vannest, K. (2016). Promoting positive behavior using the good behavior game. Journal of Positive Behavior Interventions, 18(3), 180- 190.doi:10.1177/1098300715592355

Donaldson, J. M., Vollmer, T. R., Krous, T., Downs, S., \& Berard, K. P. (2011). An evaluation of the good behavior game in kindergarten classrooms. Journal of Applied Behavior Analysis, 44(3), 605-609.doi:10.1901/jaba.2011.44-605

Gini, G., Albiero, P., Benelli, B., \& Altoè, G. (2008). Determinants of adolescents' active defending and passive bystanding behavior in bullying. Journal of Adolescence, 31(1), 93105.doi:10.1016/j.adolescence.2007.05.002

Hogg \& Vaughan. 2011. Social psychology $\left(6^{\text {th }} e d\right)$. London: Prentice Hall.

Howard, A. M., Landau, S., \& Pryor, J. B. (2013). Peer bystanders to bullying: Who wants to play with the victim?. Journal of Abnormal Child Psychology, 42(2), 265276.doi:10.1007/s10802-013-9770-8

Huitsing, G., Snijders, T. A. B., Van Duijn, M. A. J., \& Veenstra, R. (2014). Victims, bullies, and their defenders: A longitudinal study of the coevolution of positive and negative networks. Development and Psychopathology, 26(03), 645- 659. doi:10.1017/s0954579414000297

Midgett, A., Doumas, D. M., Trull, R., \& Johnson, J. (2017). Training students who occasionally bully to be peer advocates: Is a bystander intervention effective in reducing bullying behavior?. Journal of Child and Adolescent Counseling, 3(1), 1-13. doi:10.1080/23727810.2016.1277116

Pozzoli, T., Gini, G., \& Vieno, A. (2012). Individual and class moral disengagement in bullying among elementary school children. Aggressive Behavior, 38(5), 378388. doi:10.1002/ab.21442

Ramaswamy, V., \& Bergin, C. (2009). Do reinforcement and induction increase prosocial behavior? Results of a teacher-based intervention in preschools. Journal of Research in Childhood Education, 23(4), 527-538. doi:10.1080/02568540909594679

Raskauskas, J. L., Gregory, J., Harvey, S. T., Rifshana, F., \& Evans, I. M. (2010). Bullying among primary school children in New Zealand: Relationships with prosocial behaviour and classroom climate. Educational Research, 52(1), 1-13. doi:10.1080/00131881003588097

Rubow, C. C., Vollmer, T. R., \& Joslyn, P. R. (2018). Effects of the good behavior game on student and teacher behavior in an alternative school. Journal of Applied Behavior Analysis, 51(2), 382-392. doi:10.1002/jaba.455

Ruiz-Olivares, R., Pino, M. J., \& Herruzo, J. (2010). Reduction of disruptive behaviors using an intervention based on the good behavior game and the say-do report correspondence. Psychology in the Schools, 47(10), 1046-1058. doi:10.1002/pits.20523

Santrock, J. W. (2015). Educational Psychology 5th ed. New York: McGraw-Hill

Schacter, H. L., \& Juvonen, J. (2018). You've got a friend (ly school): Can school prosocial norms

Song, J., \& Oh, I. (2017). Investigation of the bystander effect in school bullying: Comparison of experiential, psychological and situational factors. School Psychology International, 38(3), 319-336. doi:10.1177/0143034317699997

Tingstrom, D. H., Sterling-Turner, H. E., \& Wilczynski, S. M. (2006). The good behavior game: 1969-2002. Behavior Modification, 30(2), 225-253.doi:10.1177/0145445503261165

Trach, J., Hymel, S., Waterhouse, T., \& Neale, K. (2010). Bystander responses to school bullying: A cross-sectional investigation of grade and sex differences. Canadian Journal of School Psychology, 25(1), 114-130.doi:10.1177/0829573509357553 
Widiastuti, Rina. (2018, Juli 23). Hari Anak Nasional, KPAI Catat Kasus Bullying Paling Banyak. TEMPO.CO. Diakses dari: https://nasional.tempo.co/read/1109584/hari-anak-nasionalkpai-catat-kasus-bullying-paling-banyak

Wijayanti, Diah. (2018). Good Behavior Game Untuk Mengurangi Perilaku Disruptif Pada Siswa Sekolah Dasar. University of Muhammadiyah Malang. http://eprints.umm.ac.id/id/eprint/38341 